\title{
STATISTICAL ASSESSMENT OF THE ROLE OF THE NATIONAL TOURISM INDUSTRY IN THE ECONOMY OF UZBEKISTAN
}

\author{
Tojieva Maxliyahon Jahongir qizi \\ Institute for Staff Advanced Training and Statistical Research, Researcher,Tashkent, \\ Uzbekistan
}

\begin{abstract}
DOI No: 10.36713/epra8844

Article DOI: https://doi.org/10.36713/epra8844
\end{abstract}

This article describes the role of tourism in the national economy, the factors influencing its development, improving the quality of services, issues and directions of statistical assessment of economic development in tourism.

KEYWORDS: tourism, quality of services, diversification, sanatoriums, recreation organizations, tourism infrastructure, tourism products, industry competitiveness

\section{INTRODUCTION}

The accelerating processes of globalization that are taking place in the world today require countries to create opportunities to address important issues through the development of the tourism industry. In particular, the development of the tourism industry, which is one of the important directions of the ongoing reforms in the country, has been identified as one of the most pressing tasks.

As stated in the Decree of the President of the Republic of Uzbekistan PF-4947 "On the Strategy for further development of the Republic of Uzbekistan", the medium-term development In the long run, it is planned to develop a program of specific measures for the implementation of the concept in 2017-2021, based on the concept of tourism development in the Republic of Uzbekistan. The implementation of these tasks will lead to an increase in the share of tourism in the economy, its rapid development and increase the quality of tourist services. Also, on the basis of the Decree of the President of the Republic of
Uzbekistan dated February 9, 2021 "On measures to further develop domestic and pilgrimage tourism in the Republic of Uzbekistan", a number of efforts are being made in this area. In recent years, Uzbekistan has taken a number of measures to develop the tourism industry, including the creation of maximum convenience, further increase the competitiveness of the industry, improve the quality of services and actively promote the national tourism product in the world market.

As a result of the measures taken, in 2019 the share of tourism in GDP was 2.6\%. In 2018, the figure was $2.4 \%$.

There is information on the number of foreign citizens visiting the Republic of Uzbekistan (Figure 1). These data show that the number of foreigners visiting our country increased sharply in 2018-2019 ( 2 times in 2018 compared to $2017,126 \%$ in 2019 compared to 2018), and by 2020 , due to the pandemic observed worldwide $(22,2 \%$ or 4.5 times less than in 2019). 


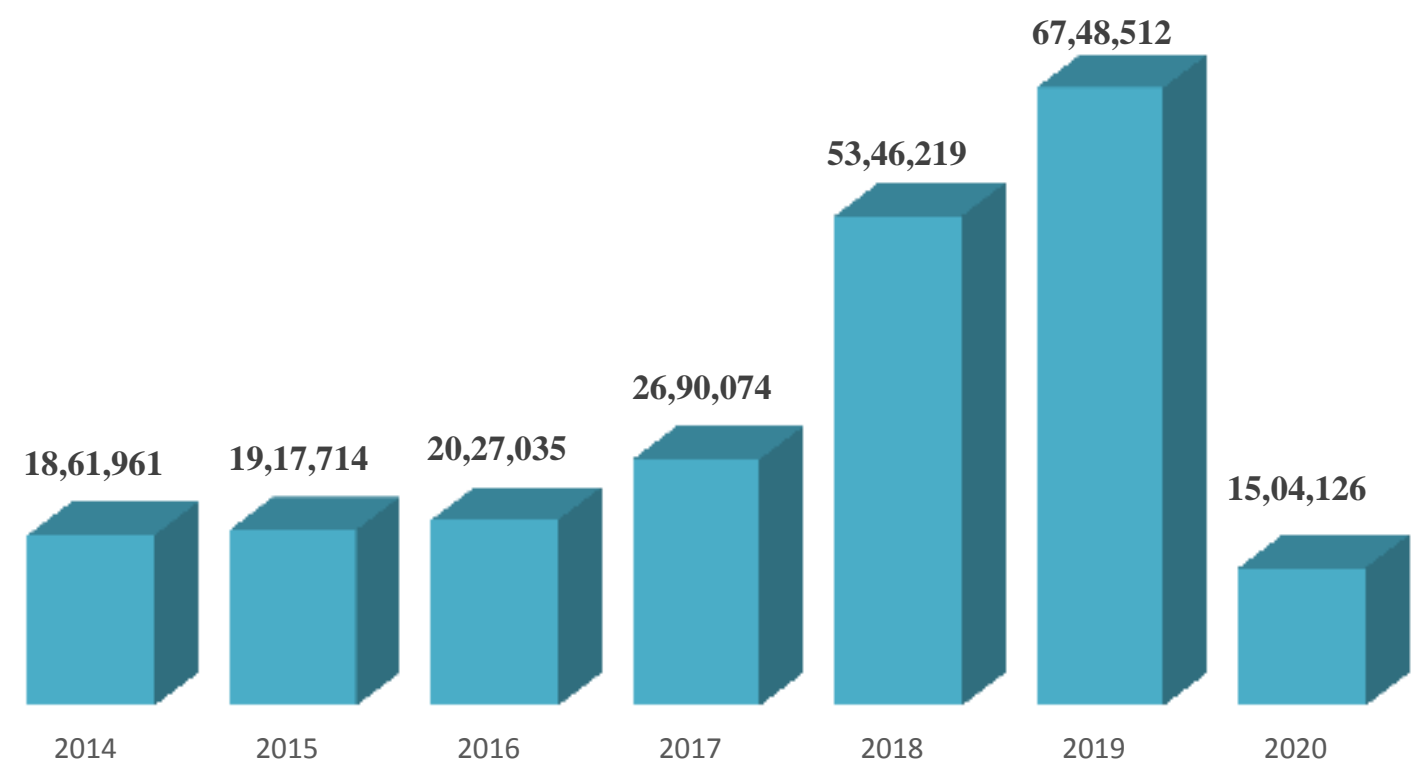

Figure 1. Information on the number of foreign citizens visiting the Republic of Uzbekistan, person

The number of organizations engaged in tourism in our country in 2014 amounted to 343 , in 2018 - 502, and by 2019 this figure reached 517. By
2020, the number of enterprises engaged in these activities due to the pandemic was 337 .

Table 1

The number of enterprises engaged in tourism activities and the number of visitors served

\begin{tabular}{|l|c|c|c|c|c|c|c|}
\hline & $\mathbf{2 0 1 4}$ & $\mathbf{2 0 1 5}$ & $\mathbf{2 0 1 6}$ & $\mathbf{2 0 1 7}$ & $\mathbf{2 0 1 8}$ & $\mathbf{2 0 1 9}$ & $\mathbf{2 0 2 0}$ \\
\hline $\begin{array}{l}\text { Number of tourism companies and } \\
\text { organizations, units }\end{array}$ & $\mathbf{3 4 3}$ & $\mathbf{3 9 8}$ & $\mathbf{4 3 3}$ & $\mathbf{4 4 9}$ & $\mathbf{5 0 2}$ & $\mathbf{5 1 7}$ & $\mathbf{3 3 7}$ \\
\hline $\begin{array}{l}\text { Number of visitors served by them, } \\
\text { thousand people }\end{array}$ & 514,1 & 560,4 & 465,4 & 670 & 713,2 & 942,0 & 212,3 \\
\hline Including: & & & & & & & \\
\hline accepted & 419 & 421,3 & 351,0 & 558,0 & 613,4 & 788,8 & 186,2 \\
\hline sent & 61,2 & 98,4 & 80,1 & 72,5 & 84,9 & 128,5 & 18,6 \\
\hline $\begin{array}{l}\text { only visa and foreign passport } \\
\text { registration, hotel and other } \\
\text { accommodation services are provided }\end{array}$ & 33,9 & 40,7 & 34,3 & 38,8 & 14,9 & 24,7 & 7,5 \\
\hline
\end{tabular}

The observed pandemic has led to a sharp decline in the flow of visitors to our country and from our country to foreign countries. As a result, there has been a sharp decline in the number of agencies and enterprises engaged in tourism activities. In this regard, today special attention is paid to the development of domestic tourism in order to maintain enterprises and organizations engaged in tourism. 


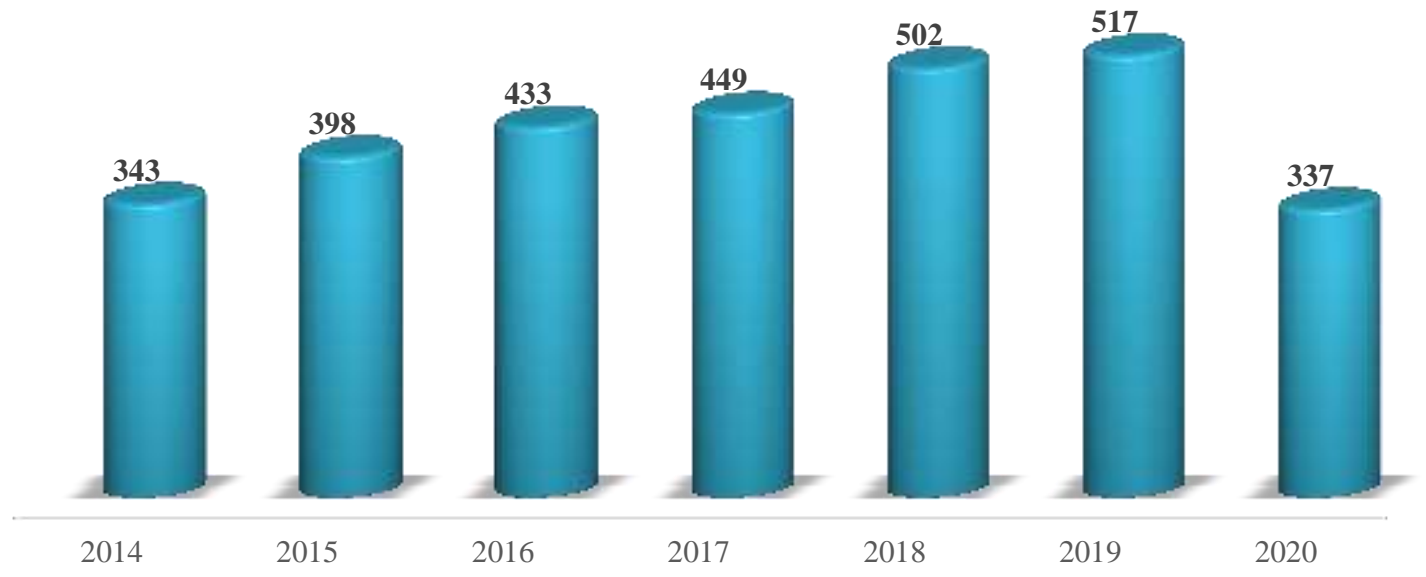

Figure 2. Number of organizations engaged in tourism activities, units.

The Decree of the President of the Republic of Uzbekistan dated February 9, 2021 "On measures to further develop domestic and pilgrimage tourism in the Republic of Uzbekistan" helps to support enterprises engaged in tourism. The Decree of the
President of the Republic of Uzbekistan dated February 9, 2021 "On measures to further develop domestic and pilgrimage tourism in the Republic of Uzbekistan" helps to support enterprises engaged in tourism.
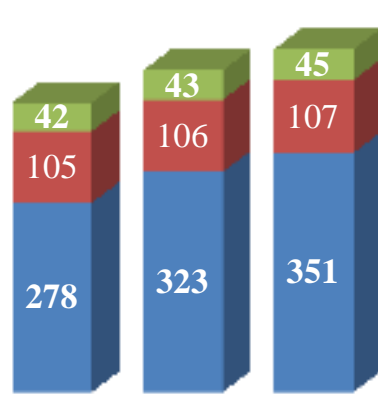

2010

\begin{abstract}
$\begin{array}{lllll}2011 & 2012 & 2013 & 2014 & 2015\end{array}$
Number of professional theaters

number of museums (including branches)

The data in the picture above shows that over the years 2010-2019, the number of enterprises and organizations providing services to tourists, in particular sanatoriums and resorts, had a tendency to increase and in 2020 decreased compared to the previous year. The number of professional theaters had an upward trend in 2010-2016 and decreased in 2016-2020. The number of museums, on the other hand, had an upward trend in 2010-2017 and
\end{abstract}

number of operating sanatoriums and recreation facilities (including tour bases)

Figure 3. Number of organizations engaged in tourism activities, units. declined sharply in 2018 .
In 2019, 230,464 people were employed in the tourism sector, while by 2020 the figure was 189,229 . In the picture below, we can see the distribution of employment in the tourism sector by sectors of the economy in 2020. It should be noted that the tourism industry does not only serve tourists. They can also serve citizens in a normal environment. Therefore, the economy is divided into tourism sectors and sectors that directly serve tourism. 


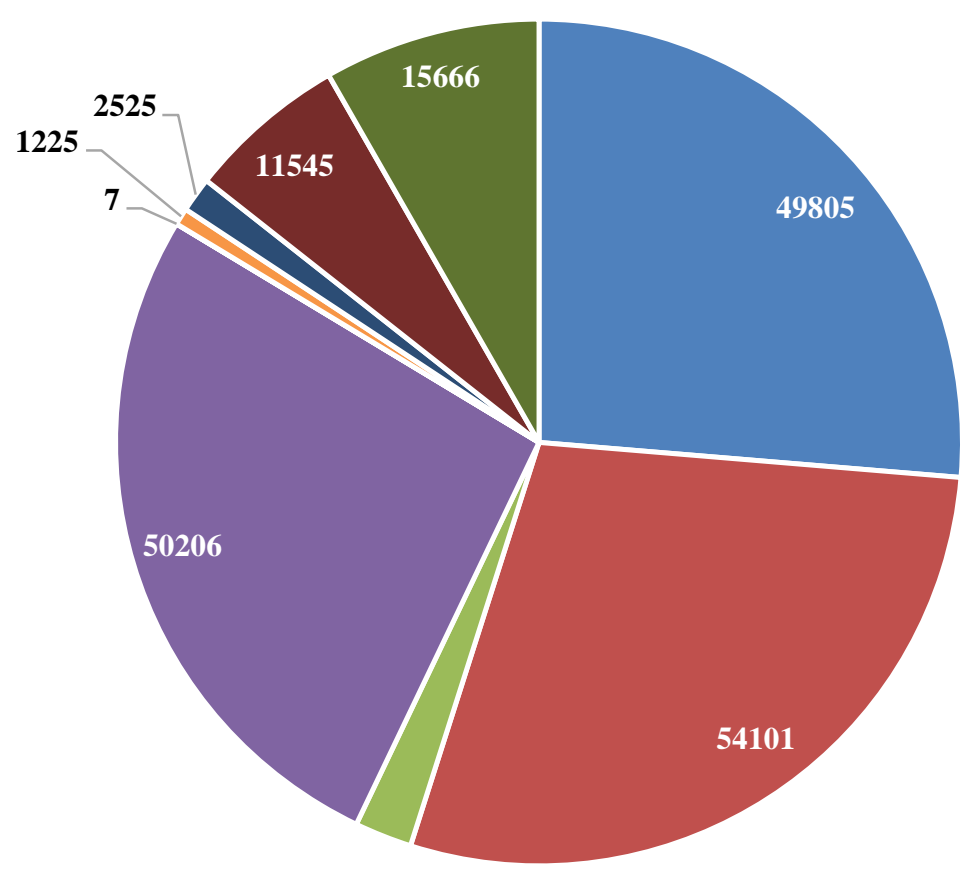

- Accommodation services

- Food and beverage delivery services

- Railway passenger transport

- Other passenger transport on land

- Air passenger transport

- Rent, hire, lease

- Activities of tour operators, travel agents and other tourism service organizations

- Cultural services

- Activities in the field of sports, recreation and entertainment

\section{Figure 4. Information on the distribution of jobs in the tourism industry in Uzbekistan in 2020, person}

As can be seen from the data above, in 2020, 54,101 people were employed in food and beverage delivery services from the tourism sector, 50,206 in other land passenger transport services and 49,805 in residential services.

In order to form a system of modern measures to support the tourism industry, it is important to have complete statistics on the state of the industry in the country and its contribution to the country's economy, as well as to compare these figures with other countries. The comparability of tourism-related indicators is explained by the compliance of tourism statistics in the country with the principles of standards developed by reputable international organizations.

In this regard, it is expedient to study the standards developed by leading international organizations for the development of the tourism industry and use them in the process of forming statistics on the industry.

\section{LIST OF USED LITERATURE}

1. Law of the Republic of Uzbekistan dated July 18, 2019 No. 549 "On Tourism".

2. Popkov V.P., Kol O.D., Anoxina E.M. Мониторинг туристского бизнеса в крупном городе: теория и практика. Моscow 2009-15, $16 \mathrm{p.}$

3. Trifonova Z.A., Trifonova M.M. Оиенка туристского потенциала территории Чувашской Республики, Чувашский государственный университет имени И.Н.Ульянова, Russia,19.01.2009 у., UDC $338.48 p$.

4. Kulakova L.I., Osipov V.A. Методические подходы к оиенке туристско-рекреационного потенциала российских регионов, Российское предпринимательство, Issue 18, № 24, December 2017, ISSN 1994-6937.

5. Commission of the European Communities. Organization for Economic Cooperation and Development, World Tourism Organization, United Nations. Tourism Satellite Account: Recommended Methodological Framework 2008 (Luxembourg, Madrid, New York, Paris, 2008).

6. Makarov М.Yи. Построение модели устойчивого развития туристских территорий (на примере Краснодарского края). Диссертачия на соискание учёной степени кандидата экономических наук. Сочи $2016-33,34 p$

7. http://www.stat.uz/ 